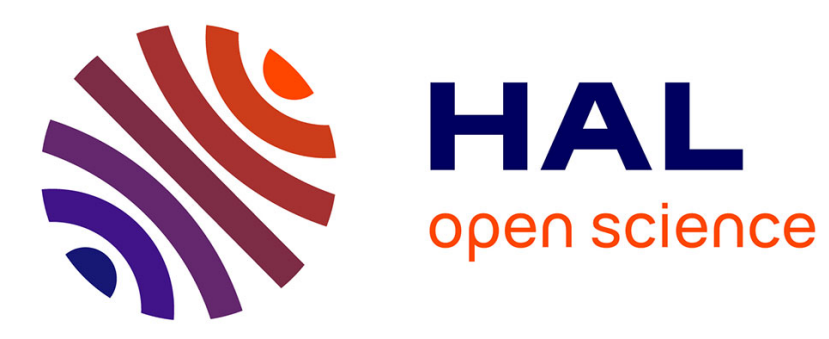

\title{
A Practical Route to Cyclobutanols and Fluorocyclobutanes
}

\author{
Vincent L Revil-Baudard, Samir Z Zard
}

\section{To cite this version:}

Vincent L Revil-Baudard, Samir Z Zard. A Practical Route to Cyclobutanols and Fluorocyclobutanes. Helvetica Chimica Acta, 2021, 104 (9), pp.e2100106. 10.1002/hlca.202100106 . hal-03416880

\author{
HAL Id: hal-03416880 \\ https://hal.science/hal-03416880
}

Submitted on 5 Nov 2021

HAL is a multi-disciplinary open access archive for the deposit and dissemination of scientific research documents, whether they are published or not. The documents may come from teaching and research institutions in France or abroad, or from public or private research centers.
L'archive ouverte pluridisciplinaire HAL, est destinée au dépôt et à la diffusion de documents scientifiques de niveau recherche, publiés ou non, émanant des établissements d'enseignement et de recherche français ou étrangers, des laboratoires publics ou privés. 


\title{
A Practical Route to Cyclobutanols and Fluorocyclobutanes
}

\author{
Vincent L. Revil-Baudard and Samir Z. Zard*
}

Laboratoire de Synthèse Organique, CNRS UMR 7652, Ecole Polytechnique, 91128 Palaiseau, France, e-mail: samir.zard@polytechnique.edu

Dedicated affectionately to Professor Peter Kündig on the occasion of his $75^{\text {th }}$ birthday

\begin{abstract}
S-(1-Acetoxycyclobut-1-yl)-O-ethyl dithiocarbonate (xanthate) 7 was found to add to electronically unbiased alkene and to certain heteroarenes. In the latter case, this corresponds to a variant of the Minisci reaction and allows the late-stage modification of biologically active substances. Saponification of the acetate furnishes the corresponding cyclobutanol, which can be converted into fluorocyclobutanes by the action of DAST. Fluorocyclobutyl substituted aromatics and heteroaromatics are increasingly present in drug candidates. Finally, S-[1-(2', 2', 2'-trifluoroethoxy)cyclobut-1-yl]-O-ethyl dithiocarbonate $\mathbf{3 0}$ was obtained unexpectedly while optimizing the synthesis of xanthate 7 and found to be a very promising reagent for the introduction of the trifluoroethoxycyclobutyl motif.
\end{abstract}

Keywords: radical addition $\bullet$ xanthates $\bullet$ cyclobutanols $\bullet$ fluorocyclobutenes $\bullet$ Minisci reaction

Small ring motifs are increasingly appearing in biologically active substances [1-6]. This trend is driven by the desire to replace an excess of aromatic subunits with saturated surrogates, thus increasing the number of $\mathrm{sp}^{3}$ carbons and escaping from the tyranny of "flatland" [7-9]. The cyclobutyl group has proven particularly useful in this respect [10-12]. A few examples of medicinally important derivatives are displayed in Figure 1. They include linsitinib (OSI-go6), a selective and orally efficacious dual inhibitor of the insulin and IGF-1 receptors) 1 [13]; CJ-1882 2, a potent and selective dopamine $D_{3}$ receptor antagonist [14]; sibutramine 3, a serotonin reuptake inhibitor developed as an antiobesity drug [15]; PF-06409577 4, a direct activator of adenosine monophosphate-activated protein kinase (AMPK) and a potential drug for the treatment of diabetic nephropathy [16]; and compounds 5 and 6, which are showing promise for the treatment of spinal muscular atrophy [17]. The cyclobutanol substructure, present in compounds $\mathbf{1}, \mathbf{2}, \mathbf{4}$, and $\mathbf{5}$ is of particular significance, both in its own right and as a stepstone to numerous other cyclobutyl groups. An illustration of the former point is the case of cyclobutanol $\mathbf{5}$, which is twice as active as cyclobutyl analogue 6 [17]

The main route to cyclobutanols is by addition of an organometallic reagent to cyclobutanones. This well-established approach is convergent and powerful, but it is limited by the incompatibility of the organometallic reagents with many polar entities and by the difficulty of implementing such methods for the late-stage modification of advanced candidates in medicinal chemistry programs. References [18-21] give academic examples of additions of pyridine derived organolithiums and Grignard reagents to cyclobutanones; many more can be found in the patent literature, reflecting the importance of such compounds for the pharmaceutical industry. We herein describe a radical based strategy that complements conventional ionic and organometallic methods and allows access to structures not readily available by more established approaches.

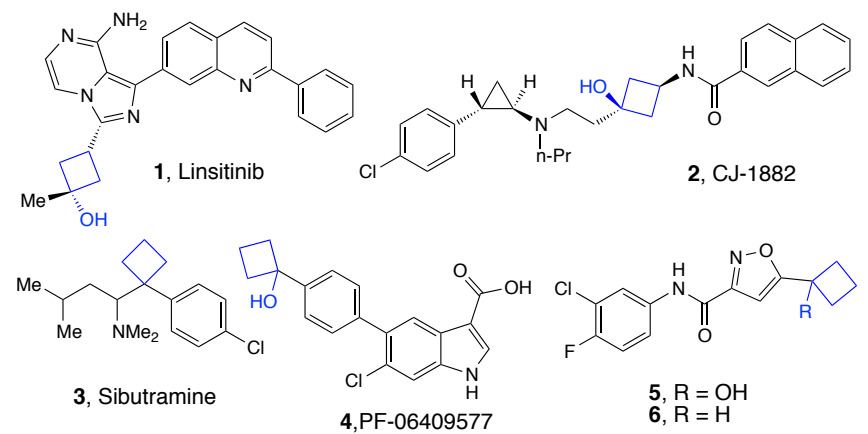

Figure 1. Examples of cyclobutyl-containing drugs.

Our foray into this area arose as part of our larger study of a novel radical chemistry of xanthates and related thiocarbonylthio derivatives and their application to solving diverse synthetic problems [22-25]. Extension of this technology to the case of cyclobutanols hinges on the accessibility of xanthate 7 and its stability and behavior under typical reaction conditions. Furthermore, as implicitly implied by the mechanistic manifold in Scheme 1 , it is important for initial radical 8 to be more stable than adduct radical 10, for otherwise the collapse of intermediate $\mathbf{1 1}$ will favor the return to starting xanthate 7 and adduct radical 10 instead of progressing forward to give desired product 12 and initial radical $\mathbf{8}$ which propagates the chain. The consequence is an increase of the concentration of adduct radical 10 relative that of initial radical $\mathbf{8}$ and therefore an increased probability for further additions to alkene 9 resulting in the formation of unwanted oligomers (via di-adduct radical 13). Incidentally, this path to oligomers and polymers can be controlled and constitutes the basis of the powerful RAFT/MADDIX technology for the manufacture of bloc copolymers [22]. This simplified analysis neglects possible polar effects which could be important and, in some cases, even decisive.

While radical $\mathbf{8}$ is tertiary and expected to be more stable than most secondary adduct radicals 10, the presence of the strained cyclobutane ring increases the s character in the SOMO orbital in radical 8 and thus acts as a destabilizing element. Thus, the cyclopropyl and cyclobutyl radicals are respectively $35 \mathrm{kj} / \mathrm{mol}$ and $7 \mathrm{kj} / \mathrm{mol}$ less stable than the little strained openchain isopropyl radical [26]. For the sake of comparison, the tertiary butyl 
radical is $5.5 \mathrm{kj} / \mathrm{mol}$ more stable than the isopropyl radicals and, importantly, an acetoxymethyl radical is $35 \mathrm{kj} / \mathrm{mol}$ more stable than a methyl radical [26]. These values, while approximate and variable depending on the method of calculation or measurement, indicate that whereas a methyl substituent might not be sufficient to overcome the destabilization due the ring strain, the acetoxy substituent in radical 8 should provide enough extra stability to ensure a good control over the chain process and limit the formation of oligomers via di-adduct radical 13.

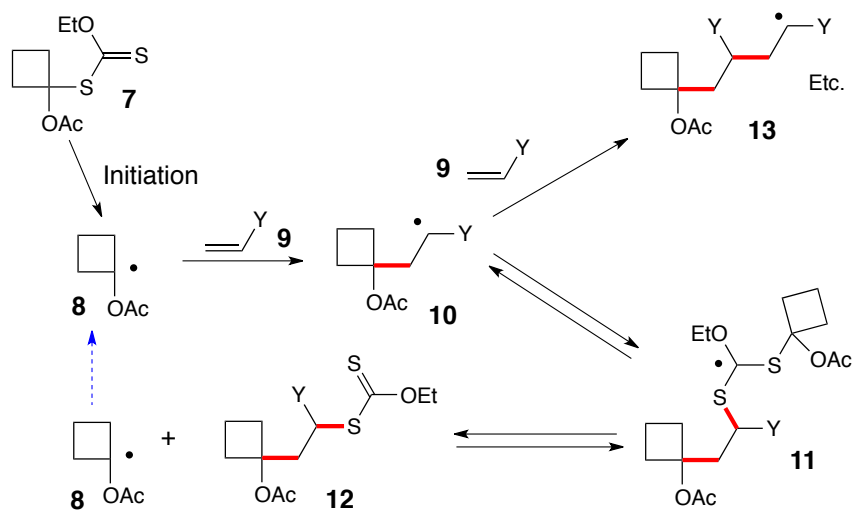

Scheme 1. Generation and addition of acetoxycyclobutyl radicals.

For the synthesis of xanthate 7, we relied on early studies by Neuenschwander on the chloro- and bromo-acylation of ketones and aldehydes [27-30]. Applied to cyclobutanone, exposure to acetyl chloride and catalytic amounts of zinc chloride leads to chloroacetate 14 (Scheme 2). Substitution with potassium $O$-ethyl xanthate furnished the desired xanthate 7 in unfortunately a vanishingly small yield of $2 \%$. We therefore decided to first isolate the fragile acetoxy chloride 14 before attempting the substitution step. The reaction of a cyclobutanone with acetyl chloride is in fact an equilibrium [27-30], which could be tilted in the forward direction by the use of $2-2.5$-fold excess acetyl chloride. We also found that aluminum trichloride, a stronger Lewis acid [31], was a more effective catalyst. Finally, we noted that vacuum distillation above $65^{\circ} \mathrm{C}$ resulted in decomposition and it was best to perform the distillation at $30{ }^{\circ} \mathrm{C}$ under 0.7 mbar of pressure. Under these conditions, the yield of acetoxy chloride 14 rose to around $80 \%$, and the reaction could be performed on an $8 \mathrm{~g}$ scale.

The substitution step, which in most cases is a trivial procedure, proved more problematic than expected. After some effort, it was found that the best yield of xanthate 7 was only $43 \%$ (31\% on a $6 \mathrm{~g}$ scale of chloride 14), when the reaction was carried out in ethanol as solvent with initial cooling to ${ }^{\circ} \mathrm{C}$. Other solvents, such as acetone, acetonitrile, diethyl ether, and isopropanol were less effective. Nevertheless, despite the modest overal yield, sufficient amounts of xanthate 7 could be produced to complete the present study.

We were pleased to find that radical addition of this xanthate to allyl acetate proceeded smoothly to give adduct $12 \mathrm{a}$ in $69 \%$, as depicted in Scheme 2. It was fortunate that xanthate 7 turned out to be more thermally stable than its chloride precursor $\mathbf{1 4}_{4}$, thus allowing it to survive the usual radical addition conditions, and that the qualitative thermochemical analysis concerning relative radical stabilities proved correct and no significant formation of oligomers was detected. Other alkenes underwent a similar addition and furnished compounds 12b-12k displayed in the lower part of Scheme 2. The cyclobutanol motif can thus be combined with numerous other functional groups, including protected amine (12b, NPhth = phthalimide), silane (12C), malonate (12e), phosphonate (12h), as well as acetal (12f) and epoxide (12g). Addition to $2 \mathrm{H}$-Thiete-1,1-dioxide gives rise to unusual compound $\mathbf{1 2 j}$ where two different 4-membered rings are linked together. Vinyl (MIDA)boronate is also a competent partner in this process, as demonstrated by the clean formation of adduct $\mathbf{1 2 k}$. Boron substituents are particularly interesting, not only from a synthetic standpoint, but also because the stability of the radical adjacent to the boron can be modulated by the choice of substituents around the boron atom. These dictate the hybridization of the boron (i. e., $\mathrm{sp}^{2}$ or $\mathrm{sp}^{3}$ ) and therefore the availability or not of an empty orbital into which the unpaired electron can delocalize [32, 33]

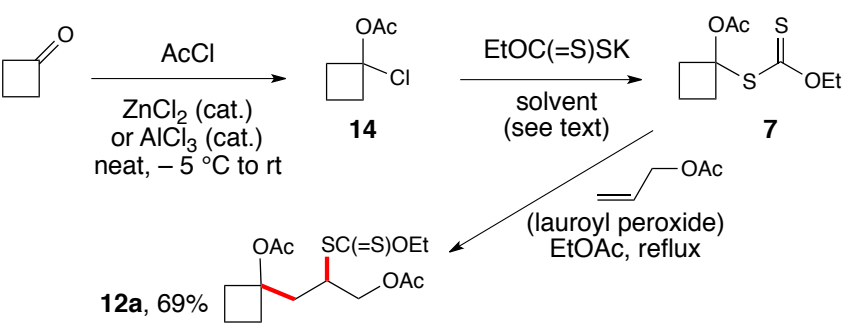

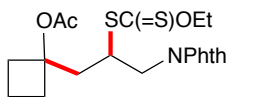

$12 b, 58 \%$

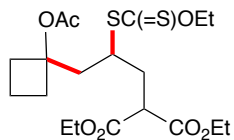

$12 \mathrm{e}, 70 \%$ PAC ${ }^{\mathrm{SC}(=\mathrm{S}) \mathrm{OEt}}$

$12 \mathrm{~h}, 42 \%$

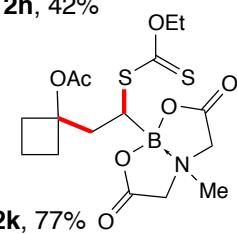

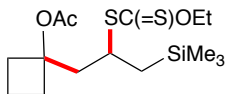

12c, $76 \%$

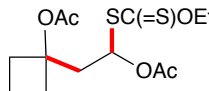

$12 d, 39 \%$

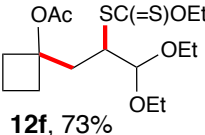

OAC $\mathrm{SC}(=\mathrm{S}) \mathrm{OEt}$
$12 i, 72 \%$

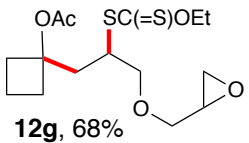

12j, $79 \%$

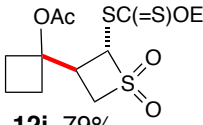

Scheme 2. Synthesis and additions of xanthate 7 to various alkenes.

In the case of adduct $\mathbf{1 2} \mathbf{k}$, the xanthate was reductively removed to give compound 15 using tris(trimethylsilyl)silane [34], a transformation that could have been applied to all other adducts. In most potential applications, the xanthate group is not needed and must be removed. Notable exceptions are products of additions to vinyl esters, as exemplified by derivative 12d, because the carbon bearing both the xanthate and the acetate has the oxidation level of an aldehyde thus opening numerous synthetic possibilities [35]. The moderate yield in the case of adduct $\mathbf{1 2} \mathbf{d}$ is due in part to the greater propensity of vinyl acetate to polymerize as compared to the other alkene partners.

Another situation where the xanthate group in the adducts can be constructively exploited is illustrated by the sequence in Scheme 3 . 


\section{HELVETICA}

Addition to protected $\mathrm{N}$-allyl aniline $\mathbf{1 5}$ furnishes the normal adduct $\mathbf{1 2}$ in a synthetically useful yield. Further exposure to stoichiometric amounts of peroxide regenerates the intermediate radical which is now forced to cyclize onto the aromatic ring to give indoline 16 in good yield [36]. Trivial saponification of the acetate produces the corresponding cyclobutanol 17, perhaps a medicinally more interesting compound. The fact that the intermediate xanthate $\mathbf{1 2}$ l can be isolated reflects the faster transfer of the xanthate group as compared to the cyclization step. Nevertheless, both steps could have been performed in the same pot, if so desired [36].

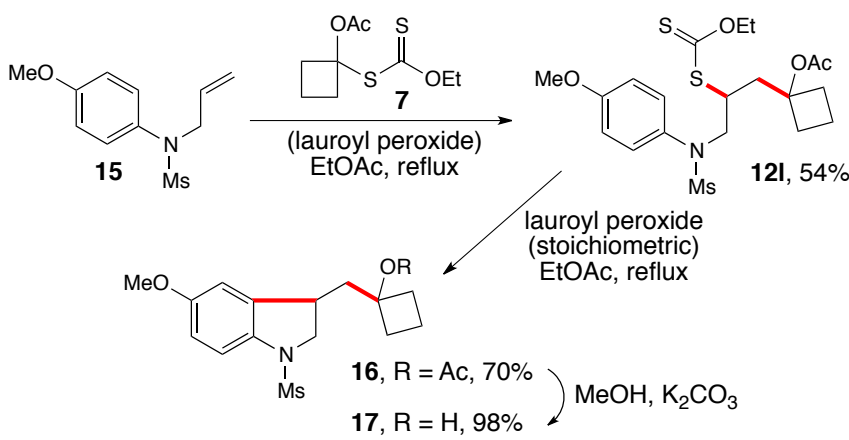

Scheme 3. Synthesis of an indoline bearing a cyclobutanol.

From a drug development perspective, the late-stage direct modification of biologically active advanced candidates is a more important goal, as it would allow for a faster and more effective optimization of their pharmacological profiles. This necessity has been the main diving force for the recent revival of the Minisci type radical chemistry [37, 38]. Xanthates can be similarly used to introduce substituents into heteroaromatic rings [39-42]. This is in fact the intermolecular version of the ring-closure process used to produce indoline 16. In these transformations, presented in generic form in Scheme 4 , the radical addition is generally reversible, and the reverse step is favored by an increase in stability of the attacking radical. The stabilization of radical 8 by the acetoxy group, which was an asset in the above addition to the alkenes, could become a liability in the reaction with heteroaromatics. It is important for the equilibrium to favor adduct radical 19 sufficiently to allow the relatively slow electron transfer to the peroxide and formation of cation 20 to take place. The other pathways leading to rearomatization, such as disproportionation of radical 19 with other radicals present in the medium, also depend on the presence of sufficient concentrations of radical 19

In the event, the results were mixed. The procedure we followed is quite practical and consisted in placing a degassed dichloroethane solution of the heteroaromatic substrate ( 1 equiv), xanthate 7 ( 2 equiv), and lauroyl peroxide (3 equiv) in a sealed vial, which was then heated at $85^{\circ} \mathrm{C}$ for one hour. In the case of basic heterocycles, one equivalent of camphorsulfonic acid (CSA) was also added prior to heating. Workup and chromatographic purification furnished the products pictured in Scheme 4

In general, the yields were moderate and the addition not as general as was initially hoped. Nevertheless, derivatives bearing a quinoline (21a), pyrazine (21b), quinoxaline (21c), pyrimidine (21d), pyridazine (21e), purine (21f), indole (219), pyridine (21h and 21i), and 4-quinolone pyrimidine-(21j). The addition products to caffein and nicotine, $\mathbf{2 1 f}$ and $\mathbf{2 1} \mathrm{h}$, respectively, represent examples of modification of biologically active natural products.

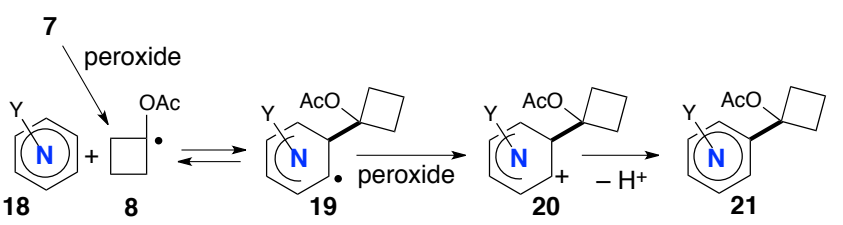

21a, 50\%<smiles>CC(=O)OC1(c2cc(C)nnc2Cl)CCC1</smiles>

21e, $44 \%$
Me 21f, $63 \%$

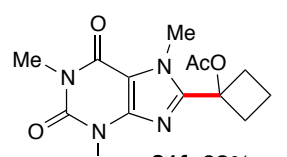

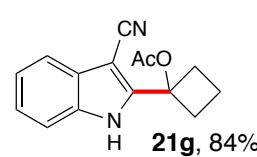

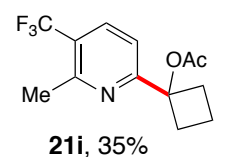

21j, $40 \% \mathrm{CF}_{3}$

21i, 35\%<smiles>CC(=O)OC1(c2ccc([C@@H]3CCCN3C)cn2)CCC1</smiles><smiles>COC1(c2cc(=O)c3cccc(C(F)(F)F)c3[nH]2)CCC1</smiles>

Scheme 4. Addition of xanthate 7 to various heteroaromatic scaffolds. Unfortunately, several heteroaromatics did not react or, in fewer instances, resulted in decomposition. These cases, displayed in Scheme 5, must be studied in more detail to understand the cause of failure, which was not expected in a few of these compounds.

No reaction

degradation<smiles>CCOC(=O)c1cn2ccccc2n1</smiles><smiles>c1ccc2scnc2c1</smiles>

Degradation<smiles>CCCCCCCNCCc1c[nH]c2ccc(OC)cc12</smiles><smiles>CC(=O)c1ccccc1C(F)(F)F</smiles><smiles>CCCc1ncc(Cl)cc1Cl</smiles>

No reaction<smiles>CCOC(=O)c1cc2ccccc2[nH]1</smiles>

No reaction<smiles>CCNC(Cc1c[nH]c2ccccc12)C(=O)O</smiles><smiles>COC(=O)c1ccc[nH]1</smiles><smiles>Cn1cc(C=O)cn1</smiles><smiles>Nc1nccs1</smiles>

Degradation

No reaction

No reaction

No reaction

No reaction

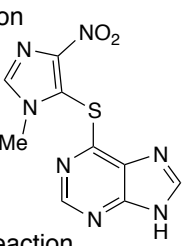

No reaction

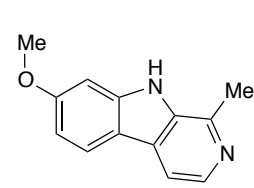

No reaction
No reaction
No reaction<smiles>CCCN(CC)CC</smiles>

Degradation

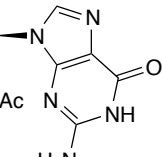

(c)

No reaction

atics that did not react with xanthate 7 .

The availability of heteroarylcyclobutanols opens access to another important family, namely 1-fluorocyclobutyl heteroarenes. This is illustrated by the synthesis, pictured in Scheme 6, of nicotine derivative 22 from acetate $\mathbf{2 1} \mathrm{h}$ by saponification and treatment with DAST. A number of biologically active fluorocyclobutyl derivatives can be found in the patent 
literature. Thus, pyrrolopyridine $\mathbf{2 3}$ and pyrimidine $\mathbf{2 4}$, from the laboratories of Abbott [43] and Merck Sharpe \& Dohme [44], respectively, are kinase inhibitors. Anthranilamide 25, discovered at Hoffmann-La Roche, is one of a family of cholesteryl ester transfer protein (CETP) inhibitors [45]. Diazepinone $\mathbf{2 6}$ from Novartis is a mGluR5 antagonist for combatting Parkinson's disease [46]. Picolinamide 27, another compound from Hoffmann-La Roche, is a cannabinoid type 2 (CB2) receptor agonist [47]. Triazole 28, designed at Merck Sharpe \& Dohme, is a ligand for GABA receptors, with potential for the treatment of anxiety and convulsions [48] Pyrazole 29, was developed by Bayer with the aim of treating, and perhaps preventing, hyperproliferative and angiogenic diseases [49].
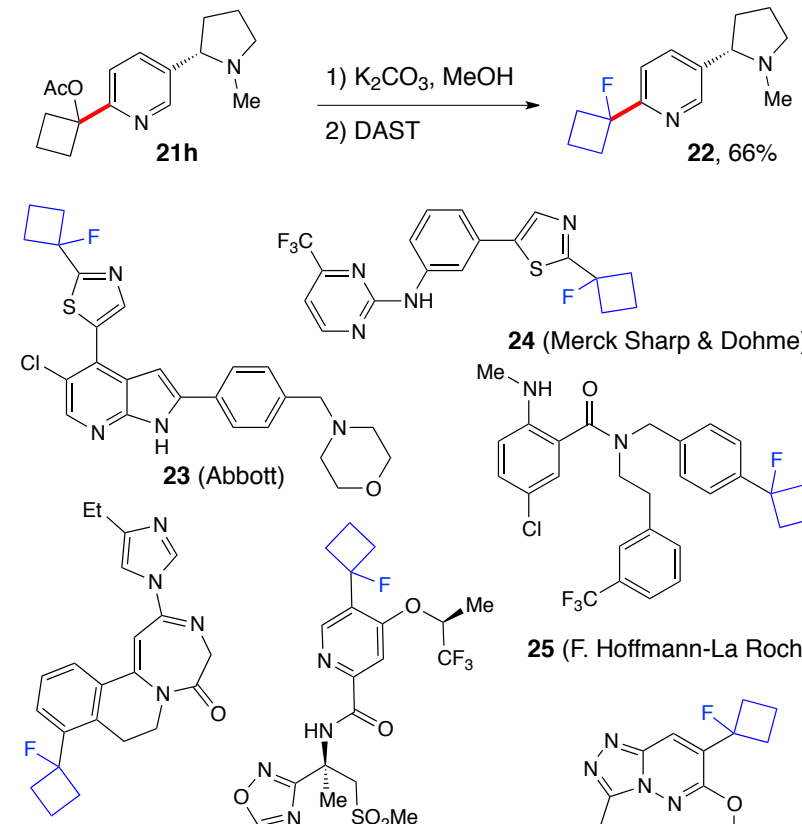

26 (Novartis)
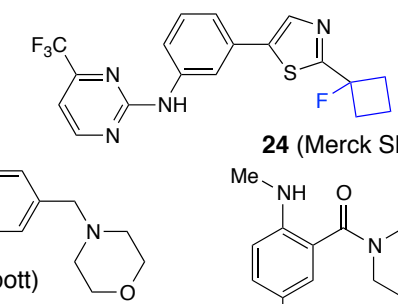

24 (Merck Sharp \& Dohme) $\mathrm{Me}$

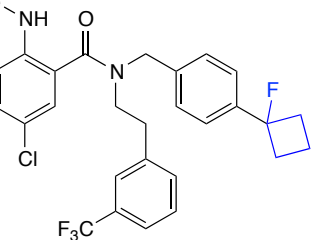

25 (F. Hoffmann-La Roche)
27 (F. Hoffmann-La Roche)

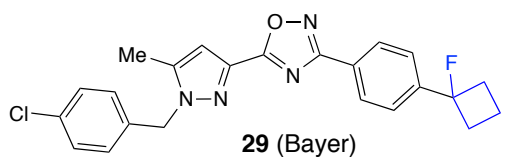<smiles>CCCC1(OC(C)=O)CCC1</smiles><smiles>CCOCn1c(C2=CCC2)c(C(F)(F)F)c2cc(Cl)ccc21</smiles>

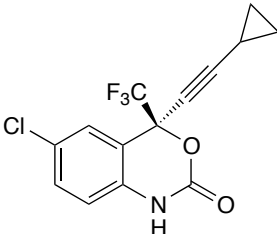

32, Efavirenz<smiles>Cn1c(=O)c2c(nc(C3=CCC3)n2C)n(C)c1=O</smiles>

Scheme 7. Synthesis of cyclobutenyl caffein.

Interestingly, while attempting to improve the synthesis of xanthate 7, we examined trifluoroethanol as the reaction solvent and isolated compound 33 from the reaction of acetoxy chloride $\mathbf{1 4}$ with the xanthate salt (Scheme 8). Obviously, trifluoroethanol somehow substituted the acetate group; but, unfortunately, the few attempts at increasing the very modest yield proved fruitless. Nevertheless, sufficient amounts were secured to allow a brief examination of its very promising reactivity. For instance, its reaction with caffein 34 furnished adduct 35 in nearly quantitative yield. Trifluoroethoxycyclobutanes are very rare compounds. Less than 5 examples of 1-aryl-1-trifluoroethoxy-cyclobutanes could be found in the REAXYS database, all prepared in the group of Creary [46-47], and none described in a medicinal chemistry context.

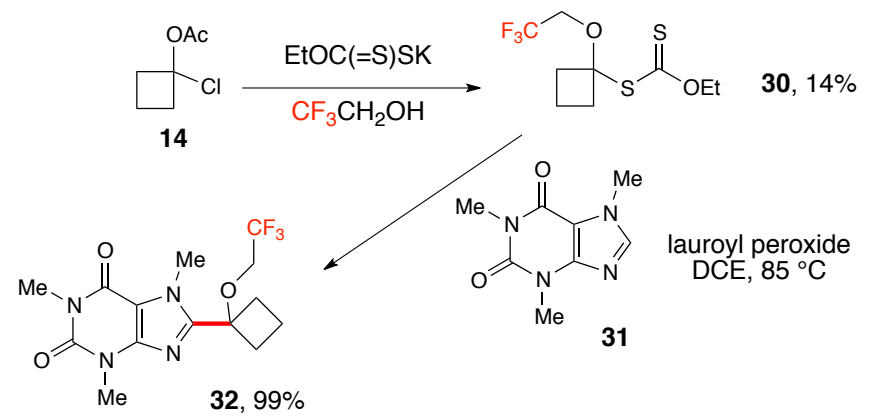

Scheme 8. Synthesis of trifluoroethoxycyclobutyl caffein.

In summary, we have described a convenient approach for the direct introduction of the cyclobutanol motif, both into aliphatic structures and into heteroaromatic rings. The latter variant is of particular relevance to medicinal chemists, who are continuously seeking practical methods for the late-stage modification of biologically active substances. This also allows an expedient access to the corresponding fluorocyclobutanes, without the current need for organometallic intermediates which have a narrower functional group tolerance, as compared to the present radical based approach. Finally, the serendipitous obtention of xanthate 33 provides an entry into novel fluorinated cyclobutyl derivatives that could prove of interesting from a drug-development perspective.

\section{Experimental Section}

Detailed experimental procedures and spectral characterization of all new compounds are provided in the accompanying supplementary Information.

\section{Acknowledgements}


We thank Bayer S. A. S. for a PhD scholarship to one of us (V.R.-B), which allowed the execution of the first experiments in this project.

We also thank Mrs. Sophie Bourcier and Mr. Vincent Jactel (both at Ecole Polytechnique) for HRMS measurements.

\section{References}

[1] G. Ernouf, E. Chirkin, L. Rhyman, P. Ramasami, J.-C. Cintrat, 'Photochemical Strain-Release-Driven Cyclobutylation of C(sp3)Centered Radicals', Angew. Chem. Int. Ed. 2020, 59, 2618-2622.

[2] J. M. Lopchuk, K. Fjelbye, Y. Kawamata, L. R. Malins, C.-M. Pan, R. Gianatassio, J. Wang, L. Prieto, J. Bradow, T. A. Brandt, M. R. Collins, J. Elleraas, J. Ewanicki, W. Farrell, O. O. Fadeyi, G. M. Gallego, J. J. Mousseau, G. M. Oliver, N. W. Sach, J. K. Smith, J. E. Spangler, H. Zhu, J. Zhu, P. S. Baran, 'Strain-Release Heteroatom Functionalization: Development, Scope, and Stereospecificity', J. Am. Chem. Soc. 2017, 139, 3209-3226.

[3] R. Gianatassio, J. M. Lopchuk, J. Wang, C.-M. Pan, L. R. Malins, L. Prieto, T. A. Brandt, M. R. Collins, G. M. Gallego, N. W. Sach, J. E. Spangler, H. Zhu, J. Zhu, P. S. Baran, 'Strain-release amination', Science 2016, 351, $241-246$.

[4] D. Barnes-Seeman, M. Jain, L. Bell, S. Ferreira, S. Cohen, X. H. Chen, J. Amin, B. Snodgrass, P. Hatsis, 'Metabolically Stable tert-Butyl Replacement', ACS Med. Chem. Lett. 2013, 4, 514-516.

[5] J. A. Burkhard, C. Guérot, H. Knust, E. M. Carreira, 'Expanding the Azaspiro[3.3] heptane Family: Synthesis of Novel Highly Functionalized Building Blocks', Org. Lett. 2012, 14, 66-69.

[6] R. Pellicciari, M. Raimondo, M. Marinozzi, M. Natalini, G. Costantino, C. Thomsen, '(S)-(+)-2-(3'-Carboxybicyclo[1.1.1]pentyl)-glycine, a Structurally New Group I Metabotropic Glutamate Receptor Antagonist', J. Med. Chem. 1996, 39, 2874-2876.

[7] F. Lovering, J. Bikker, C. Humblet, 'Escape from Flatland: Increasing Saturation as an Approach to Improving Clinical Success', J. Med. Chem. $2009,52,6752-6752$

[8] M. Aldeghi, S. Malhotra, D. L. Selwood, A. W. E. Chan, 'Two- and threedimensional rings in drugs', Chem. Biol. Drug Des. 2014, 83, 450-461.

[9] T. P. Stockdale, C. M. Williams, 'Pharmaceuticals that contain polycyclic hydrocarbon scaffolds', Chem. Soc. Rev. 2015, 44, 7737-7763.

[10] E. M. Carreira, T. C. Fessard, 'Four-Membered Ring-Containing Spirocycles: Synthetic Strategies and Opportunities', Chem. Rev. 2014, $114,8257-8322$.

[11] J. C. Namyslo, D. E. Kaufmann, 'The Application of Cyclobutane Derivatives in Organic Synthesis', Chem. Rev. 2003, 103, 1485-1537.

[12] M. L. Wrobleski, G. A. Reichard, S. Paliwal, S. Shah, H.-C. Tsui, R. A. Duffy, J. E. Lachowicz, C. A. Morgan, G. B. Varty, N.-Y. Shih, 'Cyclobutane derivatives as potent NK1 selective antagonists', Bioorg. Med. Chem. Lett. 2006, 16, 3859-3863.

[13] M. J. Mulvihill, A. Cooke, M. Rosenfeld-Franklin, E. Buck, K. Foreman, D. Landfair, M. O'Connor, C. Pirritt, Y. Sun, Yao, L. D. Arnold, N. W. Gibson, Q. S. Ji, 'Discovery of OSI-906: A selective and orally efficacious dual inhibitor of the IGF-1 receptor and insulin receptor', Future Med. Chem. 2009, 1, 1153-1171.
[14] J. Chen, B. Levant, C. Jiang, T. M. Keck, A. H. Newman, S. Wang, 'Tranylcypromine Substituted cis-Hydroxycyclobutylnaphthamides as Potent and Selective Dopamine D3 Receptor Antagonists', J. Med. Chem. 2014, 57, 4962-4968.

[15] C. A. Luque, J. A. Rey, 'The discovery and status of sibutramine as an antiobesity drug', Eur. J. Pharmacol. 2002, 440, 119-128.

[16] K. O. Cameron, D. W. Kung, A. S. Kalgutkar, R. G. Kurumbail, R. Miller, C. T. Salatto, J. Ward, J. M. Withka, S. K. Bhattacharya, M. Boehm, K. A. Borzilleri, J. A. Brown, M. Calabrese, N. L. Caspers, E. Cokorinos, E. L. Conn, M. S. Dowling, D. J. Edmonds, H. Eng, D. P. Fernando, R. Frisbie, D. Hepworth, J. Landro, Y. Mao, F. Rajamohan, A. R. Reyes, C. R. Rose, T. Ryder, A. Shavnya, A. C. Smith, M. Tu, A. C. Wolford, J. Xiao, 'Discovery and preclinical characterization of 6-chloro-5-[4-(1hydroxycyclobutyl)phenyl]-1H- indole-3-carboxylic acid (PF-06409577), a direct activator of adenosine monophosphate-activated protein kinase (AMPK), for the potential treatment of diabetic nephropathy', J. Med. Chem. 2016, 59, 8068-8081.

[17] A. Rietz, H. Li, K. M. Quist, J. J. Cherry, C. L. Lorson, B. Burnett, N. L. Kern, A. N. Calder, M. Fritsche, H. Lusic, P. J. Boaler, S.-W. Choi, X. Xing, M. A. Glicksman, G. D. Cuny, E. J. Androphy, K. J. Hodgetts, 'Discovery of a Small Molecule Probe that Post-translationally Stabilizes the Survival Motor Neuron Protein for the Treatment of Spinal Muscular Atrophy', $J$. Med. Chem. 2017, 60, 4594-4610.

[18] Z. J. Garlets, B. D. Wertz, W. Liu, E. A. Voight, H. M. L. Davies, Regio- and 'Stereoselective Rhodium(II)-Catalyzed $\mathrm{C}-\mathrm{H}$ Functionalization of Cyclobutanes', Chem 2020, 6, 304-313.

[19] A. I. Subota, A. O. Lutsenko, B. V. Vashchenko, D. M. Volochnyuk, V. Levchenko, Y. V. Dmytriv, E. B. Rusanov, A. O. Gorlova, S. V. Ryabukhin, O. O. Grygorenko, 'Scalable and Straightforward Synthesis of All Isomeric (Cyclo)alkylpiperidines', Eur. J. Org. Chem. 2019, 3636-3648.

[20] A. I. Subota, O. O. Grygorenko, Y. B. Valter, M. A. Tairov, O. S. Artamonov, D. M. Volochnyuk, S. V. Ryabukhin, 'Approach to 3-(Cyclo)alkylpiperidines through 'sp3-sp3 via sp2-sp3' Coupling', Synlett 2015, 26, 408-411.

[21] G. F. Alberici, J. Andrieux, G. Adam, M. M. Plat, 'Synthesis of tobacco alkaloids via tertiary azides', Tetrahedron Lett. 1983, 24, 1937-1940.

[22] B. Quiclet-Sire, S. Z. Zard, 'The Degenerative Radical Transfer of Xanthates and Related Derivatives: An Unusually Powerful Tool for the Creation of Carbon-Carbon Bonds', Top Curr. Chem. 2006, 264, 201-236.

[23] B. Quiclet-Sire, S. Z. Zard, 'Fun with Radicals: Some New Perspectives for Organic Synthesis', Pure Appl. Chem. 2010, 83, 519-551.

[24] B. Quiclet-Sire, S. Z. Zard, 'On the Strategic Impact of the Degenerative Transfer of Xanthates on Synthetic Planning', Isr. J. Chem. 2017, 57, 202-217.

[25] S. Z. Zard, 'Discovery of the RAFT/MADIX Process. Mechanistic Insights and Polymer Chemistry Implications', Macromolecules 2020, 53, 8144-8159.

[26] J. Hioe, H. Zipse 'Radical Stability — Thermochemical Aspects' in 'Encyclopedia of Radicals in Chemistry, Biology and Materials Free Radical Reactions in Preparative Organic Chemistry', ed C. Chatgilialoglu, A. Studer, John Wiley \& Sons Ltd, Chichester, 2012, pp 449-476.

[27] R. Kyburz, H. Schaltegger, M. Neuenschwander, 'Eine neue Fulvensynthese', Helv. Chim. Acta, 1971, 54, 1037-1046.

[28] M. Neuenschwander, P. Bigler, K. Christen, R. Iseli, R. Kyburz, H. Mohle, 'Chloracylierung und Bromacylierung von Carbonylverbindungen: Eine in Vergessenheit geratene Carbonylreaktion. I. Präparative Anwendungsbreite', Helv. Chim. Acta 1978, 61, 2047-2058. 
[29] P. Bigler, H. Mühle, M. Neuenschwander, 'Chloroacylierung und Bromoacylierung von Carbonylverbindungen: Eine in Vergessenheit geratene Carbonylreaktion', Synthesis 1978, 593-594.

[30] M. Neuenschwander, 'The Forgotten Carbonyl Reaction: Chloroacetylation and Bromoacetylation of Carbonyl Compounds', Helv. Chim. Acta 2015, 98, 899912.

[31] G. Hilt, F. Pünner, J. Möbus, V. Naseri, M. A. Bohn, A Lewis Acidity Scale in Relation to Rate Constants of Lewis Acid Catalyzed Organic Reactions, Eur. J. Org. Chem. 2011, 5962-5966.

[32] B. Quiclet-Sire, S. Z. Zard, 'Radical Instability in Aid of Efficiency. A Powerful Route to Highly Functional MIDA Boronates, J. Am. Chem. Soc. 2015, 137, $6762-6765$

[33] Q. Huang, J. Michalland, S. Z. Zard, S. Z. 'Alternating Radical Stabilities. A Convergent Route to Terminal and Internal Boronates', Angew. Chem. Int. Ed. 2019, 58, 16936-16942.

[34] C. Chatgilialoglu, C. Ferreri, Y. Landais, V. I. Timokhin, 'Thirty Years of (TMS $)_{3} \mathrm{SiH}:$ A Milestone in Radical-Based Synthetic Chemistry', Chem. Rev. 2018, 118, 6516-6572.

[35] B. Quiclet-Sire, S. Z. Zard, 'Xanthates and Vinyl Esters, a Remarkably Powerful Alliance', Heterocycles 2019, 99, 742-765.

[36] S. Z. Zard, 'The Xanthate Route to Indolines, Indoles, and their Aza Congeners', Chem. Eur. J. 2020, 26, 12689-12705.

[37] F. Minisci, R. Bernardi, F. Bertini, R. Galli, M. Perchinummo, 'Nucleophilic character of alkyl radicals-VI: A new convenient selective alkylation of heteroaromatic bases', Tetrahedron 1971, 27, 3575-3579.

[38] M. A. Duncton, 'Minisci reactions: Versatile CH-functionalizations for medicinal chemists', J. MedChem Comm 2011, 2, 1135-1161.

[39] Y. M. Osornio, R. Cruz-Almanza, V. Jiménez-Montaño, L. D. Miranda, 'Efficient intermolecular, oxidative radical alkylation of heteroaromatic systems under "tin-free" conditions', Chem. Commun. 2003, 18, 2316-2317.

[40] M.-G. Braun, G. Castanedo, L. Qin, P. Salvo, S. Z. Zard, 'Introduction of Trifluoroethylamine as Amide Isostere by $\mathrm{C}-\mathrm{H}$ Functionalization of Heteroarenes', Org. Lett. 2017, 19, 4090-4093.

[41] Q. Huang, S. Z. Zard, 'An Inexpensive Radical Methylation and Related Alkylations of Heteroarenes' Org. Lett. 2018, 20, 1413-1416.

[42] V. L. Revil-Baudard, J.-P. Vors, S. Z. Zard, 'Xanthate Mediated Incorporation of Quaternary Centers into Heteroarenes', Org. Lett. 2018, 20, 3531-3535.

[43] M. R. Michaelides, A. S. Judd, S. R. Fix-Stenzel, R. F. Clark, B. K. Sorensen, Z. $\mathrm{Ji}$, 'Pyrrolopyridine and Pyrrolopyrimidine Inhibitors of Kinases', US Pat. US2011/281842 2011.

[44] M. D. Altman, B. M. Andresen, K. L. Arrington, K. K. Childers, M. E. Di Francesco, A. Donofrio, J. M. Ellis, C. Fischer, D. J. Guerin, A. M. Haidle, S. Kattar, S. L. Knowles, C. Li, J. Lim, M. R. Machacek, A. B. Northrup, B. M. O'boyle, R. D. Otte, A. Petrocchi, M. H. Reutershan, E. Romeo, T. Siu, B. M. Taoka, B. W. Trotter, H. Zhou, J. Burch, B. Cote, K. Dupont-Gaudet, J.-F. Fournier, J. Y. Gauthier, D. Guay, J. S. Robichaud, J. Grimm, M. L. Maddess, A. J. Schell, K. B. Spencer, H. C. Woo, S. Bhat, 'Aminopyrimidines as Syk Inhibitors', Int. Pat. WO2011075515 2011.

[45] A. Conte, H. Kuehne, T. Luebbers, P. Mattei, C. Maugeais, W. Mueller, P. Pflieger, 'Anthranilamide/2-Amino-Heteroarene Carboxamide Derivatives', Int. Pat. WO2007090752 2007.

[46] D. Behnke, D. Carcache, P. Ertl, M. Koller; D. Orain, 'Diazepinone Derivatives', US Pat. US2014/57902 2014

[47] U. Grether, A. Kimbara, M. Nettekoven, F. Ricklin, S. Roever, M. Rogers-Evans, D. Rombach, T. Schulz-Gasch, M. Westphal, 'Pyridine-2-amides useful as CB2 agonists', Int. Pat. WO2014/86805 2014.

[48] W. R. Carling, J. L. Castro Pineiro, I. J. Collins, A. R. Guiblin, T. Harrison, A. Madin, K. W. Moore, M. G. Russell, G. Scott, L. J. Street, 'Triazolo-pyridazine derivatives as ligands for GABA receptors’, US Pat. US6579875 2003.
[49] M. Harter, H. Beck, P. Ellinghaus, K. Berhorster, S. Greschat, K.-H. Thierauch, 'Aryl compounds with aminoalkyl substituents and their use', US Pat. US2011312930 2011

[50] M. Gazvoda, M. Krivec, Z. Časar, J. Košmrlj, 'En Route to 2-(Cyclobuten-1-yl)3-(trifluoromethyl)-1H-indole', J. Org. Chem. 2018, 83, 2486-2493.

[51] P. Natho, Z. Yang, L. A. T. Allen, J. Rey, A. J. P. White, P. J. Parsons, 'An entry to 2-(cyclobut-1-en-1-yl)-1H-indoles through a cyclobutenylation/deprotection cascade', Org. Biomol. Chem. 2021, 19, 4048-4053. 


\section{Entry for the Table of Contents}

((Insert TOC Graphic here; max. width: $17.5 \mathrm{~cm}$; max. height: $7.0 \mathrm{~cm})$ )

\section{Twitter}

Cyclobutanols and fluorocyclobutanes derived therefrom of interest to medicinal chemists can be obtained by addition of S-(1acetoxycyclobutyl)-O-ethyl xanthate to alkenes and to certain heteroarenes. 